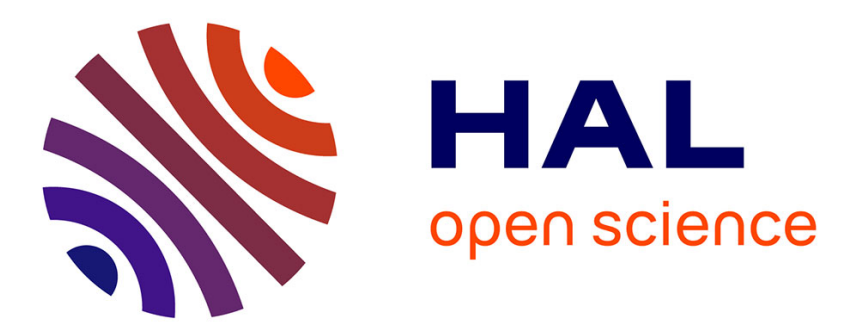

\title{
Reduplication in languages: A case study of languages of China
}

Dan Xu

\section{To cite this version:}

Dan Xu. Reduplication in languages: A case study of languages of China . Dan Xu. Plurality and Classifiers across languages in China, 2012. hal-01386244

\section{HAL Id: hal-01386244 \\ https://hal.science/hal-01386244}

Submitted on 31 Oct 2016

HAL is a multi-disciplinary open access archive for the deposit and dissemination of scientific research documents, whether they are published or not. The documents may come from teaching and research institutions in France or abroad, or from public or private research centers.
L'archive ouverte pluridisciplinaire $\mathbf{H A L}$, est destinée au dépôt et à la diffusion de documents scientifiques de niveau recherche, publiés ou non, émanant des établissements d'enseignement et de recherche français ou étrangers, des laboratoires publics ou privés. 


\title{
2 Reduplication in languages: A case study of languages of $\mathrm{China}^{1}$
}

\begin{abstract}
Reduplication is widely attested in human languages, especially in the southern hemisphere. This distribution, often complementary with plural markings, is also found in languages spoken in China, which show a correlation between plural marking and reduplication/classifiers: if reduplication and classifiers are found extensively, then plural marking is not developed, and is sensitive to the semantic feature [+human]. The more plural marking is developed, such as in Altaic languages, the less this semantic feature is required. The more a language possesses a developed plural-marking morphology, the less it needs reduplication and classifiers. Subjectivity plays a key role in reduplicated adjectives. Reduplication is iconically motivated. Positive degree constitutes its core meaning. Reduplication with negative meaning characterizes the grammaticalization process from icon to symbol.
\end{abstract}

Key words: reduplication, iconicity, motivation, plurality, typology

\section{Introduction}

Reduplication can be defined as proposed by Carl Rubino (2005): "the repetition of phonological material within a word for semantic or grammatical purposes". This definition follows the one formulated by Sapir (1921: 76), that reduplication is "repetition of all or part of the radical element." According to Sapir (1921: 76), reduplications "indicate such concepts as distribution, plurality, repetition, customary activity, increase of size, added intensity, continuance". It is now well known that reduplication is a widely used morphological device in human languages. Due to language typology research, we have access to a vast amount of data from different languages covering almost the whole world. Today a crosslanguage approach to reduplication is possible and necessary.

For almost one century, the wide distribution and the high frequency of reduplication in languages has drawn the attention of many linguists including Sapir (1921: 76-78) who noticed that in numerous languages such as Chinese,

1 The present work was supported by the grant 'Quantification et Pluralité' ANR-06-BLAN-0259 awarded by the Research Department of the French Government and by the University Institute of France. 
Tibetan, Manchu, Somali, Chinook (spoken in the United States), Tsimshian (spoken in Canada and the United States), Ewe (spoken in Togo, Ghana), and so on, "this fundamental function can be quoted from all parts of the globe". Since the 70's, more investigations have been done on this topic. The paper written by Moravcsik (1978) is representative, including numerous examples in diverse languages. Recent research in English on reduplication can be found in the book edited by B. Hurch (2005), which includes twenty-four papers discussing reduplication in the world's languages, and doesn't leave out child language or sign languages. Several Asian languages are also concerned, including Indonesian, Modern Hindi and Japanese. The Chinese language and other languages of China, which widely use the device of reduplication, are absent however. Papers collected by A. Michaud and A. Morgenstern (eds. 2007) show us the current investigations on this subject in France. Besides studies of different language families, the article by $\mathrm{M}-\mathrm{C}$. Paris denotes how reduplication is exploited in contemporary Chinese as one of its important morphological means. Since this phenomenon in Chinese and languages of China (which mainly include different language families such as Sino-Tibetan, Altaic, Miao-Yao and Tai) is so common, papers and articles written in Chinese are abundant, but not wellknown by linguists outside of China.

In spite of the great variety of languages described by scholars, essential characteristics wonderfully converge into the following meanings which in general denote "increased quantity". A reduplicated noun can indicate:

- Totality:

Lomongo (spoken in Congo-Kinshasa): wané 'day', wané wané 'the whole day', nkésa 'morning', nkésa nkésa 'the whole morning' (Ait-Hamou 1979: 19)

- Plurality:

Bontoc Igorot (spoken in Philippines): anak 'child', ananak 'children' (Sapir 1921: 78). Washo (Indian language of Nevada): gusu 'buffalo', gususu 'buffaloes' (Sapir 1921: 78). Mantauran (Rukai): savare 'jeune homme', asavasavare 'jeunes hommes' (Zeitoun 2007: 46)

- Distribution:

Mandarin Chinese: renren 'everyone'. Yoruba: odún 'year', odoodún 'every year' (Ait-Hamou 1979: 23). Hiligaynon (Malayo-Polynesian): baláy 'house', baláybaláy 'every house' (Kiyomi 1995: 1152).

A reduplicated verb or adjective can express:

- Intensification:

Fa d'Ambô Creole Portuguese: féyu 'ugly', fé féyu 'very ugly' (Gulf of Guinea; Post 1998, cited by Rubino 2005: 24). Maya: zac 'white', zazac 'very white' (AitHamou 1979: 73). Mantauran (Rukai): ma-poli 'white', ma-poli-poli 'very white' (Zeitoun 2007: 45) 
- Repetition of action:

Jamaican Creole English: biit 'beat, whip', biit-biit 'whip constantly' (Bailey 1966, cited by Rubino 2005: 24).

- Continuity:

Jamaican Creole English: taak 'talk', taak-taak 'talk continuously' (Bailey 1966, cited by Rubino 2005: 24). Ambrym (Malayo-Polynesian): mün 'drink', münmün 'to keep on drinking' (Kiyomi 1995: 1158).

- Frequency of action:

Mantauran (Rukai): tamako 'fumer', tamakomako 'fumer souvent' (Zeitoun 2007: 46).

If we summarize the significance of the above functions, the metaphor carried by them is "more of form is more of content" (Lakoff and Johnson 1980: 127). As these authors indicate, form and content are linked in our conceptual system because long words are expected to contain more content. In other words, "linguistic expressions are containers, and their meanings are the content of those containers" (Lakoff and Johnson 1980: 127). This metaphor is applicable to most languages of the world, and the generalization can be expressed as follows (Lakoff and Johnson 1980: 128):

A noun stands for an object of a certain kind.

More of the noun stands for more objects of that kind.

A verb stands for an action.

More of the verb stands for more of the action (perhaps until completion).

Even though exceptions exist in some languages (we will expand on this in section 3), the metaphor established by the mentioned authors seems to be general and universal. Normally speaking, a reduplicated word (noun or verb) increases in the majority of cases the quantity of an entity or of an action.

The present paper is divided into four sections. In Section 1 I will briefly present reduplication devices in the world languages based on WALS (World Atlas of Language Structures). More details will be given in section 2 on reduplication in languages of China. These data are based on different works published in China. Section 3 will deal with the motivation of reduplication in order to understand such a largely distributed morphological process. Concluding remarks will be offered in section 4 .

\section{Reduplication in world languages}

Since the essential function of reduplication consists of increasing quantity in languages, our initial working hypothesis is to compare it with other devices 
indicating quantity, such as nominal plurality markings and numeral classifier structures. Some scholars such as Greenberg (1972) and Sanches (1973) notice that obligatory plural markings and numeral classifiers do not, in most cases, co-occur in human languages (see also counterexamples by Walter Bisang in this volume). More precisely, languages using classifiers do not possess obligatory plural marking. We will add a new parameter, reduplication, in order to compare these three criteria, because three of them share the function of marking quantity in languages.

Thanks to the authors of WALS, who provided us with a large corpus of precious information ${ }^{2}$, we have been given the opportunity of investigating numerous languages, including those which are less well-known and studied.

If we count languages which have obligatory plural marking and reduplication separately, WALS's statistics show 133/291 languages have the first device and 312/368 languages use the second. They also tell us that a reduced number of languages have numeral classifiers: 78/400 languages use this device. However, if these languages do not overlap completely, it is difficult to compare these statistics. Let us look at some statistics provided by WALS about different feature combinations between nominal plurality, numeral classifiers and reduplication. When two features are combined, the available number of languages is considerably decreased. Let us observe the situation in which occurrence of nominal plurality and numeral classifiers are combined in WALS. Just over one hundred languages indicate plurality. Among these languages, 45 have obligatory plural marking, while 43 have optional plural marking. 12 languages only mark human nouns, but the marking is obligatory. The same map shows that most (88) of these languages do not have numeral classifiers. Consequently, the correlation between plural marking and classifiers seems to be confirmed again in a larger corpus. Comparing plural marking and reduplication in a feature combination map, we notice that among 116 languages available in WALS, 91 use reduplication while 25 languages (most of them concentrated in Europe) ignore it. This suggests to us that like plural marking, reduplication constitutes one of the major devices of indicating plurality in human languages. However the statistics cannot be used safely since often the languages presented in WALS do not totally overlap with respect to the three required features. For this reason, I have chosen 61 languages which all are classified with the required three features, i.e. plural marking (PL), reduplication (R) and classifiers (CL) which are available in WALS (see Table 1).

First of all, some symbols must be clarified. "+” means that the feature is present and “-” indicates that it is absent. The symbol " \pm " implies that the

2 Language statistics based on the WALS site, November 2009. 


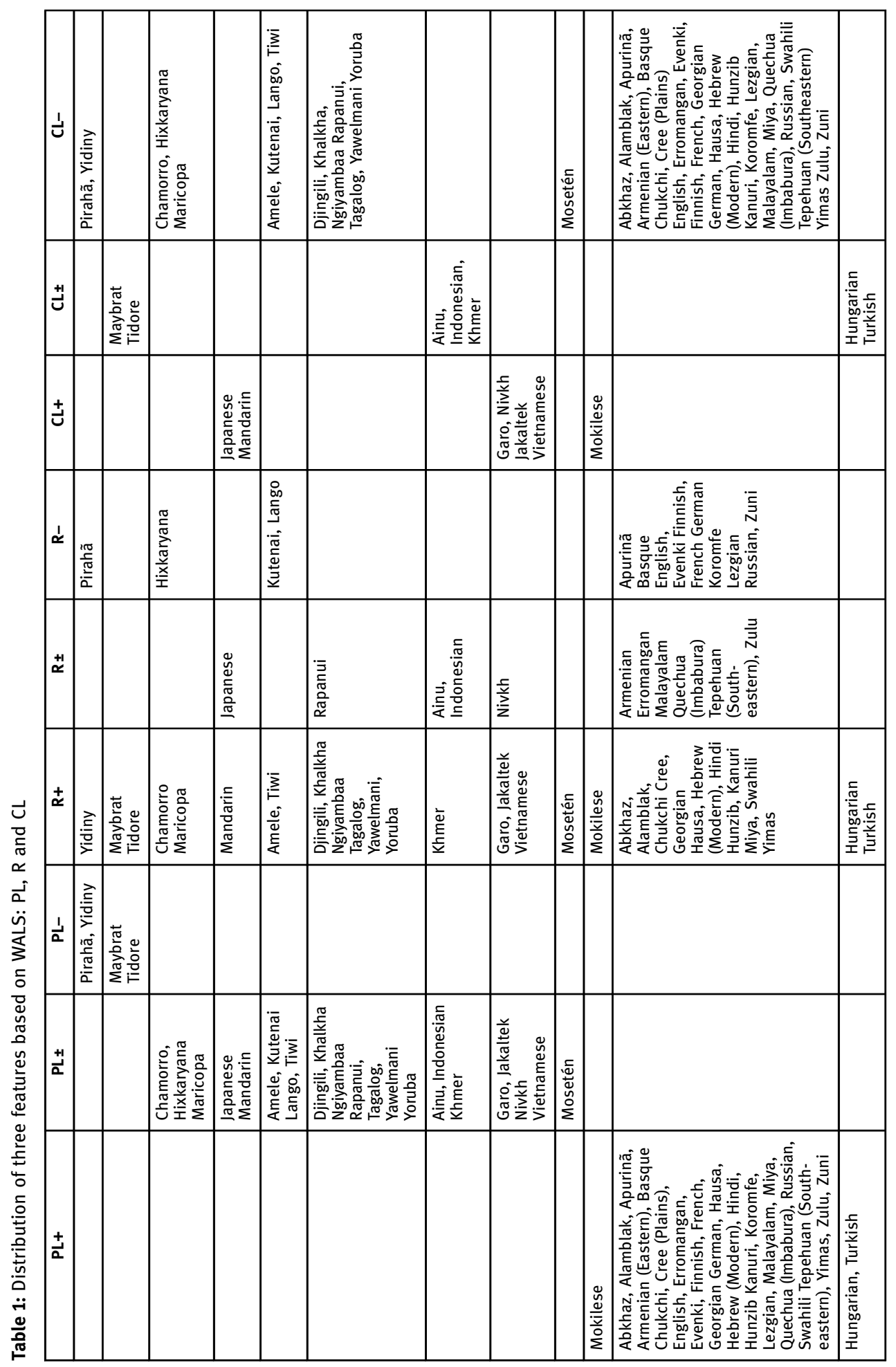


feature is present but with some constraints such as "optional”, "only human nouns”, "only full reduplication”, etc. Thus the symbol “ \pm ” loosely includes different constraints, facilitating broad observation. From Table 1 it can bee seen that languages generally use two of these three devices, and that if they possess the third one, it is often optional and not obligatory. Languages using three of them, such as Mokilese spoken in Micronesia (hundreds of small islands in the western Pacific Ocean), or none of them, like Pirahã (spoken in Brazil), are definitely rare. Within these 61 available languages, 33 of them have plural marking which can apply to all nouns and is always obligatory. It is interesting to see that almost the same proportion, 35 languages, use the device of reduplication to indicate plurality, intensification, etc. Out of 61 languages, 47 do not possess classifiers. Among them, 11 employ obligatory plural marking and completely ignore reduplication, including Basque, English, French, German ${ }^{3}$, etc.

Table 1 shows some general tendencies in these languages from around the world:

1. Languages having obligatory plural marking do not possess classifiers (30/33) (see Greenberg 1972 and Sanches 1973). Out of 33 languages with obligatory plural marking, 16 are compatible and 11 are incompatible with reduplication. The rest (the last 6 ones) accept reduplication to some degree.

2. Languages which do not employ obligatory plural marking tend to seek reduplication to compensate the lack. Out of 24 languages using non-strict plural marking, 21 (5 of them only use full reduplication) utilize the device of reduplication. Three languages which do not have plural marking at all use productive reduplication: Yidiny (spoken in Australia), Maybrat (spoken in Indonesia) and Tidore (also spoken in Indonesia).

As I have mentioned in point 1, 11 languages lacking reduplication have obligatory plural marking, while only three languages, Hixkaryana (spoken in Brazil), Kutenai (spoken in the States and Canada), and Lango (spoken in Uganda), do not have reduplication but have a plural system (non-obligatory). In this regard, the real exception is Pirahã (spoken in a hunter-gatherer tribe in Brazil) which possesses neither plural marking nor reduplication and classifiers.

The distribution of reduplication in human languages is impressive, as Carl Rubino (2005: 22) indicates:

3 Cases like "very very tall" in English, "noir noir" in French and "Film Film" in German are not taken into account since reduplication is not productive in these languages. 
Reduplication can be found in several areas of the world that are genetically quite diverse. One such area is the India subcontinent where reduplicative morphemes can be found in languages spanning several families, e.g. Indo-European, Dravidian, Austro-Asiatic and Tibeto-Burman. The Horn of Africa is yet another area where reduplication plays an important role in various languages of distinct families, e.g. Nilo-Saharan and Afro-Asiatic (Omotic, Cushitic, and Semitic) families [...]

Looking at the maps provided by WALS gives the impression that languages using reduplication devices heavily are distributed in the southern hemisphere and concentrated in a zone including Asia and Australia. Austronesian languages also seem to be incorporated. Abbi (1991, cited by Zhang Min 1997: 39) thinks that reduplication is one of the linguistic areal features of the Indian subcontinent and of Southeast Asia.

Data on languages spoken in China are not provided sufficiently in WALS. They are often less studied or even unattested in the English literature since most research is published in Chinese. They are especially interesting if we compare them with other languages of the world. We will see that they present a different pattern and more complex combinations.

\section{Reduplication in languages of China}

Our data is based on diverse publications in Chinese. Apart from books and articles on different languages spoken in China, a recent book Zhongguo de yuyan [Languages of China], published in 2007 and edited by Sun, Hu and Huang, is also used to compare and complete the information given by other scholars. Sometimes their descriptions and comments are divergent and difficult to reconcile because the authors often used heterogeneous criteria. The "sources" column presents the original reference giving the information seen in corresponding lines, and some comments have been added.

The data is very interesting for general linguistics since most non-Han languages ${ }^{4}$ spoken in China are given in Table 2. Sino-Tibetan languages (including subgroups such as Tibeto-Burman, Tai and Hmong-Mien), Austro-Asian languages and Altaic languages (with Turkic, Mongolian and Tungusic), are listed in the following table. These rich documents will complete the data offered by WALS in the Asian area.

4 Austronesian languages and Indo-European languages are not present in Table 2 since they are not widespread in Mainland China. 
Table 2: Distribution of the features of PL (Plural marking), R (Reduplication) and CL (Classifiers) in languages in China.

\begin{tabular}{|c|c|c|c|c|c|}
\hline Languages & vo/ov & PL & $\mathbf{R}$ & CL & Sources \\
\hline \multicolumn{6}{|c|}{ Tibeto-Burman groups of Sino-Tibetan languages } \\
\hline \multicolumn{6}{|c|}{ Tibetan } \\
\hline $\begin{array}{l}\text { 瑪曲藏語 } \\
\text { Mǎqǔ Zàngyǔ }\end{array}$ & OV & $\begin{array}{c}\stackrel{+}{[+\mathrm{H}] \text { and }[-\mathrm{H}]} \\
\text { distinct mark }\end{array}$ & + & + & Zhou, MC. 2003 \\
\hline $\begin{array}{l}\text { 倉洛語 } \\
\text { Cāngluò yǔ }\end{array}$ & OV & $\begin{array}{c}+ \\
+ \\
{[+\mathrm{H}] \text { and }[-\mathrm{H}]} \\
\text { same mark }\end{array}$ & + & + & Zhang, JCh. 1986 \\
\hline $\begin{array}{l}\text { 門巴語 } \\
\text { Ménbā yǔ }\end{array}$ & OV & $\begin{array}{c}+ \\
{[+\mathrm{H}] \text { and }[-\mathrm{H}]} \\
\text { same mark }\end{array}$ & + & + & Lu, ShZ. 2002 \\
\hline $\begin{array}{l}\text { 白馬 } \\
\text { Báimă }\end{array}$ & OV & $\stackrel{+}{[+A]}$ & + & + & $\begin{array}{l}\text { Zhongguo de yuyan } \\
\text { Sun, HK. et al. } 2007\end{array}$ \\
\hline \multicolumn{6}{|c|}{ Yi } \\
\hline $\begin{array}{l}\text { 铺語 } \\
\text { Yíyǔ }\end{array}$ & OV & not seen & + & + & $\begin{array}{l}\text { Zhongguo de yuyan } \\
\text { Sun, HK., et al. } 2007\end{array}$ \\
\hline $\begin{array}{l}\text { 拉祜 } \\
\text { Lāhù }\end{array}$ & OV & $\stackrel{+}{+}$ & + & + & $\begin{array}{l}\text { Chang, HE., et al. } \\
1986\end{array}$ \\
\hline $\begin{array}{l}\text { 納西 } \\
N a \grave{x} \bar{I}\end{array}$ & OV & $\stackrel{+}{[+\mathrm{H}]}$ & + & + & He and Jiang 1985 \\
\hline $\begin{array}{l}\text { 桑孔 } \\
\text { Sāngkǒng }\end{array}$ & OV & $\begin{array}{c}+ \\
{[+\mathrm{H}] \text { and }[-\mathrm{H}]} \\
\text { same mark }\end{array}$ & + & + & Li, YS. 2002 \\
\hline $\begin{array}{l}\text { 卡卓 } \\
\text { Kăzhuó }\end{array}$ & OV & $\begin{array}{c}+ \\
+[+\mathrm{H}] \text { and }[-\mathrm{H}] \\
\text { distinct mark }\end{array}$ & + & + & Mu, ShH. 2003 \\
\hline $\begin{array}{l}\text { 柔若 } \\
\text { Róuruò }\end{array}$ & OV & $\begin{array}{c}+ \\
++\mathrm{H}] \text { and }[-\mathrm{H}] \\
\text { distinct mark }\end{array}$ & + & + & Sun, HK., et al. 2002 \\
\hline $\begin{array}{l}\text { 白語 } \\
\text { Báiyǔ }\end{array}$ & vo & $\begin{array}{c}+ \\
{[+\mathrm{H}] \text { and }[-\mathrm{H}]} \\
\text { distinct mark }\end{array}$ & + & + & Xu and Zhao 1984 \\
\hline
\end{tabular}




\begin{tabular}{|c|c|c|c|c|c|}
\hline Languages & vo/ov & PL & $\mathbf{R}$ & CL & Sources \\
\hline \multicolumn{6}{|c|}{ Jingpo } \\
\hline $\begin{array}{l}\text { 獨龍 } \\
\text { Dúlóng }\end{array}$ & OV & $\stackrel{+}{[+\mathrm{H}]}$ & + & + & $\begin{array}{l}\text { Zhongguo de yuyan } \\
\text { Sun, HK., et al. } 2007\end{array}$ \\
\hline $\begin{array}{l}\text { 蘇龍 } \\
\text { Sūlóng }\end{array}$ & OV & $\begin{array}{c}+ \\
++\mathrm{H}] \text { and }[-\mathrm{H}] \\
\text { distinct mark }\end{array}$ & - & + & Li, DQ. 2004 \\
\hline $\begin{array}{l}\text { 景頗語 } \\
\text { Jǐngpōyǔ }\end{array}$ & OV & $\begin{array}{c}+ \\
{[+\mathrm{H}] \text { and }[-\mathrm{H}]} \\
\text { same mark }\end{array}$ & + & + & Dai and Jiang 2004 \\
\hline $\begin{array}{l}\text { 格曼 } \\
\text { Gémàn }\end{array}$ & OV & $\begin{array}{c}+ \\
++\mathrm{H}] \text { and }[-\mathrm{H}] \\
\text { distinct mark }\end{array}$ & + & + & Li, DQ. 2002 \\
\hline $\begin{array}{l}\text { 阿儂 } \\
\text { Anóng }\end{array}$ & OV & $\begin{array}{c}+ \\
{[+\mathrm{H}] \text { and }[-\mathrm{H}]} \\
\text { same mark }\end{array}$ & + & + & Sun and Liu 2005 \\
\hline \multicolumn{6}{|c|}{ Burman } \\
\hline $\begin{array}{l}\text { 浪速 } \\
\text { Làngsù }\end{array}$ & OV & $\begin{array}{c}+ \\
++\mathrm{H}] \text { and }[-\mathrm{H}] \\
\text { distinct mark }\end{array}$ & + & + & Dai, QX. 2005 \\
\hline $\begin{array}{l}\text { 阿昌 } \\
\bar{A} \text { chāng }\end{array}$ & OV & - & + & + & $\begin{array}{l}\text { Zhongguo de yuyan } \\
\text { Sun, HK. et al. } 2007\end{array}$ \\
\hline $\begin{array}{l}\text { 載瓦 } \\
\text { Zǎiwă }\end{array}$ & OV & $\begin{array}{c}+ \\
+ \\
{[+\mathrm{H}] \text { and }[-\mathrm{H}]} \\
\text { distinct mark }\end{array}$ & + & + & $\begin{array}{l}\text { Zhongguo de yuyan } \\
\text { Sun HK. et al. } 2007\end{array}$ \\
\hline \multicolumn{6}{|c|}{ Qiang } \\
\hline $\begin{array}{l}\text { 美語 } \\
\text { Qiāngyǔ }\end{array}$ & OV & $\begin{array}{c}+ \\
++\mathrm{H}] \text { and }[-\mathrm{H}] \\
\text { same mark }\end{array}$ & + & + & Liu, Guangkun 1998 \\
\hline $\begin{array}{l}\text { 普米 } \\
\text { Pǔmı̌ }\end{array}$ & OV & $\begin{array}{c}+ \\
{[A]}\end{array}$ & + & + & Lu, ShZ. 2001 \\
\hline $\begin{array}{l}\text { 嘉絨 } \\
\text { Jiāróng }\end{array}$ & OV & $\begin{array}{c}+ \\
++\mathrm{H}] \text { and }[-\mathrm{H}] \\
\text { same mark }\end{array}$ & + & + & Xiang, BL. 2008 \\
\hline $\begin{array}{l}\text { 史興 } \\
\text { Shǐxing }\end{array}$ & OV & $\begin{array}{c}+ \\
{[+\mathrm{H}] \text { and }[-\mathrm{H}]} \\
\text { distinct mark }\end{array}$ & + & + & Xu, Dan 2009a \\
\hline $\begin{array}{l}\text { 木雅 } \\
\text { Mù yă }\end{array}$ & OV & $\begin{array}{c}+ \\
++\mathrm{H}] \text { and }[-\mathrm{H}] \\
\text { same mark }\end{array}$ & + & + & $\begin{array}{l}\text { Zhongguo de yuyan } \\
\text { Sun, HK., et al. } 2007\end{array}$ \\
\hline
\end{tabular}




\begin{tabular}{|c|c|c|c|c|c|}
\hline Languages & vo/ov & PL & $\mathbf{R}$ & CL & Sources \\
\hline $\begin{array}{l}\text { 爾龔 } \\
\text { Ér gōng }\end{array}$ & OV & $\begin{array}{c}+ \\
{[+\mathrm{H}] \text { and }[-\mathrm{H}]} \\
\text { same mark }\end{array}$ & + & + & $\begin{array}{l}\text { Zhongguo de yuyan } \\
\text { Sun, HK., et al. } 2007\end{array}$ \\
\hline $\begin{array}{l}\text { 爾蘇 } \\
\text { Ěr Sū }\end{array}$ & OV & $\begin{array}{c}+ \\
++\mathrm{H}] \text { and }[-\mathrm{H}] \\
\text { same mark }\end{array}$ & + & + & $\begin{array}{l}\text { Zhongguo de yuyan } \\
\text { Sun, HK., et al. } 2007\end{array}$ \\
\hline \multicolumn{6}{|c|}{ Tai (Dong-Tai) group } \\
\hline $\begin{array}{l}\text { 拉珈 } \\
\text { Läjiā }\end{array}$ & Vo & - & + & + & $\begin{array}{l}\text { Mao, ZW. et al. } \\
1982\end{array}$ \\
\hline $\begin{array}{l}\text { 壯語 (武鳴) } \\
\text { Zhuàngyǔ (Wǔmíng) }\end{array}$ & vo & - & + & + & $\begin{array}{l}\text { Zhang, Junru. et al. } \\
1999\end{array}$ \\
\hline $\begin{array}{l}\text { 莫話 } \\
\text { Mòhuà }\end{array}$ & VO & - & + & + & Yang, TY. 2000 \\
\hline $\begin{array}{l}\text { 拉基語 } \\
\text { Lājīyŭ }\end{array}$ & vo & - & + & + & Li, YB. 2000 \\
\hline $\begin{array}{l}\text { 標話 } \\
\text { Biāohuà }\end{array}$ & vo & - & + & + & Liang and Zhang 2002 \\
\hline $\begin{array}{l}\text { 木佬 } \\
\text { Mùlăo }\end{array}$ & vo & $\stackrel{+}{\text { only family members }}$ & + & + & Bo, WZ. 2003 \\
\hline $\begin{array}{l}\text { 布央 } \\
\text { Bùyāng }\end{array}$ & vo & - & + & + & Li, JF. 1999 \\
\hline \multicolumn{6}{|c|}{ Hmong-Mien (Miao-Yao) group } \\
\hline $\begin{array}{l}\text { 苗語 } \\
\text { Miáoyǔ }\end{array}$ & vo & - & + & + & Wang, FSh. et al. 1985 \\
\hline $\begin{array}{l}\text { 勉語 } \\
\text { Miănyǔ }\end{array}$ & vo & - & + & + & Mao, ZW. 2004 \\
\hline $\begin{array}{l}\text { 布努 } \\
\text { Bùnǔ }\end{array}$ & vo & $\stackrel{+}{\text { only family members }}$ & + & + & $\begin{array}{l}\text { Mao, ZW. et al. } \\
1982\end{array}$ \\
\hline $\begin{array}{l}\text { 昫奈語 } \\
\text { Jiŏngnài-yǔ }\end{array}$ & vo & $\stackrel{+}{\text { only family members }}$ & + & + & Mao and Li 2002 \\
\hline \multicolumn{6}{|c|}{ Austro-Asian languages } \\
\hline $\begin{array}{l}\text { 克载語 } \\
\text { Kèmièyǔ }\end{array}$ & vo & - & + & + & Chen, GQ. 2005 \\
\hline $\begin{array}{l}\text { 莽語 } \\
\text { Măngyǔ }\end{array}$ & vo & - & + & + & Gao, YQ. 2003 \\
\hline $\begin{array}{l}\text { 京語 } \\
\text { Jīngyǔ }\end{array}$ & vo & - & + & + & $\begin{array}{l}\text { Ouyang, et al. } \\
1984\end{array}$ \\
\hline
\end{tabular}




\begin{tabular}{|c|c|c|c|c|c|}
\hline Languages & vo/ov & PL & $\mathbf{R}$ & CL & Sources \\
\hline $\begin{array}{l}\text { 俫語 } \\
\text { Láiyǔ }\end{array}$ & vo & - & + & + & Li XL. 1999 \\
\hline $\begin{array}{l}\text { 布賡 } \\
\text { Bügēng }\end{array}$ & vo & - & + & + & Li, YB. 2005 \\
\hline $\begin{array}{l}\text { 布興 } \\
\text { Bùxīng }\end{array}$ & vo & - & - & + & Gao, YQ. 2004 \\
\hline $\begin{array}{l}\text { 克木 } \\
\text { Kèmù }\end{array}$ & vo & - & + & + & Chen, GQ. 2002 \\
\hline \multicolumn{6}{|c|}{ Altaic languages } \\
\hline \multicolumn{6}{|c|}{ Turkic } \\
\hline $\begin{array}{l}\text { 撒拉 } \\
\text { Sālā }\end{array}$ & ov & $\begin{array}{c}\stackrel{+}{[+\mathrm{H}] \text { and }[-\mathrm{H}]} \\
\text { same mark }\end{array}$ & + & $+^{5}$ & Lin, LY. 1985 \\
\hline $\begin{array}{l}\text { 哈薩克 } \\
\text { Hāsàkè } \\
\text { Qazaq }\end{array}$ & ov & $\begin{array}{c}+ \\
{[+\mathrm{H}] \text { and }[-\mathrm{H}]} \\
\text { same mark }\end{array}$ & $\begin{array}{l}? \\
+6\end{array}$ & - & $\begin{array}{l}\text { Zhongguo de yuyan } \\
\text { Sun, HK. et al. } 2007 \\
\text { Chen, Xiaoyun } 1998\end{array}$ \\
\hline $\begin{array}{l}\text { 維吾爾 } \\
\text { Wéiwúěr }\end{array}$ & ov & $\begin{array}{c}+ \\
{[+\mathrm{H}] \text { and }[-\mathrm{H}]} \\
\text { same mark }\end{array}$ & \pm & + & $\begin{array}{l}\text { Zhongguo de yuyan } \\
\text { Sun, HK. et al. } 2007\end{array}$ \\
\hline \multicolumn{6}{|c|}{ Mongolian } \\
\hline $\begin{array}{l}\text { 蒙古 } \\
\text { Měnggǔ }\end{array}$ & ov & $\begin{array}{c}\stackrel{+}{[+\mathrm{H}] \text { and }[-\mathrm{H}]} \\
\text { same mark }\end{array}$ & -7 & - & $\begin{array}{l}\text { Zhongguo de yuyan } \\
\text { Sun, HK. et al. } 2007\end{array}$ \\
\hline $\begin{array}{l}\text { 土族 } \\
\text { Tǔzú }\end{array}$ & OV & $\begin{array}{c}+ \\
{[+\mathrm{H}] \text { and }[-\mathrm{H}]} \\
\text { same mark }\end{array}$ & - & - & $\begin{array}{l}\text { Zhongguo de yuyan } \\
\text { Sun, HK. et al. } 2007\end{array}$ \\
\hline $\begin{array}{l}\text { 達㲦爾 } \\
\text { Dáwöér }\end{array}$ & OV & $\begin{array}{c}\stackrel{+}{[+\mathrm{H}] \text { and }[-\mathrm{H}]} \\
\text { same mark }\end{array}$ & - & - & $\begin{array}{l}\text { Zhongguo de yuyan } \\
\text { Sun, HK. et al. } 2007\end{array}$ \\
\hline $\begin{array}{l}\text { 東鄉 } \\
\text { Dōngxiāng }\end{array}$ & ov & $\begin{array}{c}+ \\
{[+\mathrm{H}] \text { and }[-\mathrm{H}]} \\
\text { same mark }\end{array}$ & - & - & $\begin{array}{l}\text { Zhongguo de yuyan } \\
\text { Sun HK. et al. } 2007\end{array}$ \\
\hline
\end{tabular}

5 According to Lin (1985: 54), classifiers are optional and some of them are loaned from Chinese.

6 In ZGDYY, this problem is not mentioned, while Chen provides abundant examples of reduplication.

7 In interrogative sentences, interrogative particles can sometimes be reduplicated. 


\begin{tabular}{|c|c|c|c|c|c|}
\hline Languages & vo/ov & PL & $\mathbf{R}$ & CL & Sources \\
\hline $\begin{array}{l}\text { 保安 } \\
\text { Băo'ān }\end{array}$ & OV & $\begin{array}{c}+ \\
{[+\mathrm{H}] \text { and }[-\mathrm{H}]} \\
\text { same mark }\end{array}$ & - & - & $\begin{array}{l}\text { Zhongguo de yuyan } \\
\text { Sun HK. et al. } 2007\end{array}$ \\
\hline \multicolumn{6}{|c|}{ Tungusic } \\
\hline $\begin{array}{l}\text { 錫伯 } \\
\text { Xībó }\end{array}$ & OV & $\begin{array}{c}+ \\
{[+\mathrm{H}] \text { and }[-\mathrm{H}]} \\
\text { same mark }\end{array}$ & - & - & $\begin{array}{l}\text { Zhongguo de yuyan } \\
\text { Sun HK. et al. } 2007\end{array}$ \\
\hline $\begin{array}{l}\text { 朝鮮 } \\
\text { Korean }\end{array}$ & ov & $\begin{array}{c}+ \\
{[+\mathrm{H}] \text { and }[-\mathrm{H}]} \\
\text { same mark }\end{array}$ & - & \pm & Jin Haiyue 2005 \\
\hline $\begin{array}{l}\text { 霂語 } \\
\text { Manchu }\end{array}$ & OV & $\begin{array}{c}+ \\
{[+\mathrm{H}] \text { and }[-\mathrm{H}]} \\
\text { same mark }\end{array}$ & + & \pm & Wang QF. 2005 \\
\hline $\begin{array}{l}\text { 鄂温克 } \\
\text { Ėwēnkè }\end{array}$ & ov & $\begin{array}{c}+ \\
{[+\mathrm{H}] \text { and }[-\mathrm{H}]} \\
\text { same mark }\end{array}$ & - & - & $\begin{array}{l}\text { Zhongguo de yuyan } \\
\text { Sun HK. et al. } 2007\end{array}$ \\
\hline
\end{tabular}

It may be noted that nominal plural marking is very sensitive to the [+Human] or [+Animate] feature in numerous languages spoken in China. The more plural marking is developed, such as in Altaic languages, the less this semantic feature is required. In the south of China, the Tibeto-Burman group presents some contrastive characteristics in the case of Tai, Hmong-Mien groups and Austro-Asian languages: on one side the Tibeto-Burman (TB) group has OV order (except Bai), while the other three (Tai, Hmong-Mien groups and AustroAsian languages) have VO order. Moreover, plural marking seems more developed in TB than the rest even though the semantic feature [ $[$ Human] is important in almost the half of these languages. Plural marking is not formed or is not necessary according to updated reports of Tai, Hmong-Mien groups and AustroAsian languages. The authors do not always give information about partial vs. full reduplication; this detail is not provided in the Reduplication column in Table 2. It is striking that except Altaic, all other languages presented in Table 2, i.e. Tibeto-Burman, Tai, Hmong-Mien groups of Sino-Tibetan and Austro-Asian languages, all use reduplication devices and classifiers. Languages which do not possess plural marking systematically appeal to both reduplication and classifiers. In other words, of these languages, none has recourse to just one device, R or CL. This suggests that in non-Han languages spoken in the south of China, reduplication and classifiers are linked or complementary devices in 
the plural marking system, perhaps due to language contact with the Chinese language, which has both features. This phenomenon is not observed in other languages of the world, since a minority of languages uses classifiers (78/400, see Section 1). Note that 12/61 languages in Table 1 use both reduplication and classifiers.

Typologically and geographically, languages in China are divided into three types as summarized in Table 3. In the north, languages are quite similar to those in Europe, with obligatory plural marking, often ignoring reduplication and classifier devices. In Altaic languages, Manchu (almost extinct) and Korean have assimilated many Chinese loan words, such as classifiers. This phenomenon has also occurred in Salar, in which measure words (these are not real classifiers and exist in all human languages) are often loaned from Chinese. It seems that the Turkic group and Tungusic group are more influenced by the Chinese languages. In the southwest, plural marking exists, as well as reduplication and classifiers, while in the southeast, languages geographically encircled by the Chinese language behave almost like it: plural marking is not developed, but reduplication and classifiers are widely used. The three situations are summarized in Table 3:

Table 3: Three types of languages spoken in China

\begin{tabular}{lllll}
\hline Languages & Altaic lgs & TB lgs & Tai, HM, Austro-A & Chinese \\
\hline Word-order & OV & OV & VO & VO \\
\hline Is plural marking devloped? & + & \pm & - & - \\
Is reduplication developed? & - & + & + & + \\
Are classifiers obligatory? & - & + & + & + \\
\hline
\end{tabular}

If we compare Table 3 with Table 1 we will see that plural marking is not only correlated with classifiers but also with reduplication. It is interesting to note that in numerous Austronesian languages, where plural marking does not exist, it is reduplication which indicates the meaning of plural. It is also clear that the more a language possesses a developed plural marking morphology, the less it needs reduplication and classifiers. These last two devices seem to be more appropriate for languages having less-developed or undeveloped plural marking, in order to compensate for the need of expressing quantification.

\section{Motivation of reduplication}

Iconicity is commonly defined as a similarity between the form of a sign and its meaning. In this section I will use this cognitive approach to explain reduplica- 
tion. Haiman (1980: 515) $)^{8}$ proposes and develops two types of iconicity: imagic iconicity and grammatic iconicity. "An iconic image is a single sign which resembles its referent with respect to some characteristics" such as photographs, statues, and onomatopoeic words in languages. He calls iconic diagram "a systematic arrangement of signs, none of which necessarily resembles its referent, but whose relationships to each other mirror the relationships of their referents". "The clearest example of such iconicity is that of sequence. Other things being equal, the order of statements in a narrative description corresponds to the order of the events they describe". Within the iconicity of grammar, Haiman distinguishes two types: (a) isomorphism (one sign and one meaning) and (b) motivation (relationships between the word order and the events). In other words, type (a) presents "the correspondence of parts" and type (b) indicates "the correspondence of relations between parts" (Croft 1990: 164). However, as Croft (1990: 171) points out, the distinction between isomorphism and iconic motivation is not always clear because of the choice of these terms. Givon (1985: 188) thinks that the distinction between isomorphic and diagrammatic "is arbitrary and not supported by traditional usage, neither in the "hard' sciences nor in philosophy." I will use Haiman's "grammatic iconicity" adopting the terms of Givón (1985), who distinguishes icon and symbol as two extreme points on a scale forming a continuum. This gradual scale is necessary and more appropriate to the analysis of reduplication, thus allowing some reduplicated words to be classified as an intermediate stage.

Reduplication is one of the iconically motivated grammatical devices, since "the structure of language directly reflects some aspect of the structure of reality." (Haiman 1980: 515). In previous sections, I stated that plural marking is relative to reduplication in human languages. Haiman (1980: 528) also classified these two grammatical means as iconically motivated: "it is universally assumed that markedness is iconically motivated" as Greenberg (cited by Haiman) points out:

There is no language in which the plural does not have some non-zero allomorphs, whereas there are languages in which the singular is expressed only by zero.

It is not surprising that marking of plural occurs more frequently than singular since, in general, the singular is much more recurrent in discourse than the plural. Reduplication is a marked device in languages. It constitutes, apart from other functions, one of the forms of plural, complementary with plural marking. Similarly, reduplication is also iconically motivated and is impressively

8 Haiman has developed two types of "iconicity" put forth by Peirce (1932). 
widespread in human languages, and its meaning is strikingly common. In most cases, reduplication expresses an increasing quantification, but in some cases it can indicate a diminution of the meaning. This case may present counterexamples to iconicity. In fact, the origin of reduplication is iconically motivated, and when reduplication becomes a morphological means (a more abstract item), the diminutive meaning is possible in some languages.

The topic of the relationships between a language and the way of expressing it was already dealt with by Greek philosophers (Pierre Swiggers, 1993: 22) In the Cratyle it is written that the sound $r$ makes some words more expressive. Chan (1996, cited by Zhang Min, preprint b: 3), notes that Chinese words that include the meaning of roundness almost always contain a rounded vowel. I add here Baxter's ${ }^{9}$ reconstruction of Old Chinese to better illustrate the phenomenon:

$\begin{array}{llll}\text { 圆 (圆) yuán } & <\text { hjwonX } & <{ }^{\star} \text { wjan } & \text { 'round', } \\ \text { 圈 quān } & <\text { gjwen } & <{ }^{\star} \text { gwrjen } & \text { 'circle', } \\ \text { 周 zhōu } & <\text { tsyun } & <{ }^{\star} \text { tjiw } & \text { 'circuit', } \\ \text { 卷 juăn } & <\text { kjwenX } & <{ }^{\star} \text { krjon? } & \text { 'roll', } \\ \text { 环 (環) huán } & <\text { hwæn } & <{ }^{\star} \text { wren } & \text { 'ring', } \\ \text { 围 (圍) wéi } & <\text { hjwij } & <{ }^{\star} \text { wjịj } & \text { 'surround', } \\ \text { 转 (轉) zhuàn } & <\text { trjwenX } & <{ }^{\star} \text { trjon? } & \text { 'rotate', } \\ \text { 旋 xuán } & <\text { zjwen } & <{ }^{\star} \text { hiswjen } & \text { 'spin', } \\ \text { 团 (團) tuán } & <\text { dawn } & <{ }^{\star} \text { don } & \text { 'ball', } \\ \text { 弧 hú } & <\text { hu } & <{ }^{\star} \text { gwa } & \text { 'curve'. }\end{array}$

Checking the pronunciation in Old Chinese, another piece of evidence supporting Chan's remark can be added: if a word does not contain a rounded vowel at the initial stage, the reconstructions in Old Chinese show that they often contained a labial velar which rounds the following element. It seems that these sound formations were iconically motivated.

It is evident that writing systems, especially the creation of Chinese characters on bones and shells, give us a clue to a cognitive mechanism which is not always attested in alphabetic languages. In the inscriptions on bones, some graphs already contained plurality information (Guo Pan 2004, Behr Wolfgang 2006, Xu Dan 2009b):

9 The reconstruction system is taken from Baxter (1992). The character is followed by the Pinyin transcription (a conventional alphabet system for Chinese), the Middle Chinese phonological system based on the Qièyùn which is the first rime dictionary dated from $601 \mathrm{AD}$, and finally by the reconstruction in Old Chinese, marked by an asterisk. 


\begin{tabular}{|c|c|c|}
\hline 然 (絲) sī & ‘silk’ & [two strands of silk], \\
\hline 森 sēn & 'forest' & [* 木 mù, three trees], \\
\hline 崩 炎 yàn & 'flame’' & [@y 火 huǒ, three fires], \\
\hline 柿 协 (協) xié & 'put force together' & [丈力 lì, three forces], \\
\hline 们友 yǒu & 'befriend' & [Х 手 shǒu, two hands], \\
\hline 众 (眾) zhòng & 'people’ & [ $\rangle$ 人 rén, three men under the sun] \\
\hline
\end{tabular}

In this list, a contemporary standard character is printed after each graph found in the bone inscriptions to facilitate comparison. It is followed by a Pinyin transcription (a conventional alphabet system for Chinese) and a translation. An interpretation of the graph form is given in square brackets. From a cognitive point of view, these writing forms confirm that "more of form is more of content" (Lakoff and Johnson 1980: 127). It is clear that an added graph form means an added quantity. These examples are likely between imagic iconicity (by their image characteristics) and diagramatic iconicity (by their relationships reflecting those in the natural world) according to Haiman's definition (1980). On the one hand, these graphs resemble images reflecting realty, and on the other hand, the degree of abstraction of these graphs is already remarkable in mirroring the relationship between these referents.

Another example favoring the hypothesis that plurality marking and reduplication are both iconically motivated is sign languages. Here I only cite the cases of Chinese Sign Language (cf. the textbook Zhongguo shouyu [Chinese Sign Language] 2003) and German Sign Language (Pfau and Steinbach, 2005). The Chinese Sign Language textbook provides examples expressing plurality. To express one person, two index fingers form the character 人 rén 'man', and to express plurality, three fingers (index, middle and ring fingers) of two hands form the character 众 zhòng 'people' in a clockwise circle. This process is quite similar, as we have just seen, to that of bone inscriptions. No single example in which a small quantity needs a repetition of the gesture is attested. According to Pfau and Steinbach (2005: 580-581), to express "children" in German Sign Language, a sideward reduplication of the whole sign is imposed and to communicate "books", a tripling (at the same place as opposed to sideward reduplication) is required. Again, the added quantity is assumed by the added gesture but not the inverse.

As has been mentioned at the beginning of this section, reduplication can also express diminution in Agta (spoken in Philippines), Nez Perce (northwestern United States), Thompson (found in Canada), and attenuation in Quileute (spoken in the United States), Swahili, Thai, Mandarin and Tagalog (Moravcsik 1978: 322323). How can we explain these counterexamples to iconicity if we confirm that 
reduplication is iconically motivated? Kiyomi (1995) distinguishes two kinds of reduplication: one is iconic and the other is non-iconic. She considers that the second one "can be compared to regular affixation" (Kiyomi 1995: 1149). I agree with her core idea proposing that reduplication in human languages can be identified at different stages of a continuum. In other words, most instances of reduplication indicating more content are iconic and some less iconic, i.e. the quantification concept is no longer prominent and in some others is non-iconic, having become a morphological means. In the last case, reduplicated words are reanalyzed: the reduplicated part has lost its original meaning, acquiring a new status: it has become a grammatical word. For example, reduplication was used for past tense (Swadesh 1971, cited by Kiyomi 1995) in old Indo-European languages. Section 1, Table 1 shows, however, that today's European languages completely lack reduplication. A gradual process may exist, and these reduplications expressing diminution must diachronically originate from iconic ones (or from other constructions). Kiyomi also hints at this, suggesting that "iconic use of reduplication seems to be more widely observed than non-iconic use. One may well assumes that the initial use of reduplication was iconic and that later noniconic interpretations were developed” (1995: 1163) $)^{10}$.

\section{Conclusion}

In this paper, I have showed that reduplication, widely found in human languages, is complementary with plural marking. They constitute different means of marking plurality. One language can have diverse types of marking to express quantity. Reduplication and plural marking represent the main types of marking attested on different continents. I have supposed that reduplication must initially be iconically motivated. The augmented quantity and the plus-degree constitute the core meaning of reduplication. Those instances of reduplication indicating a diminution or a smaller quantity should be derived from the iconic ones, and have become a morphological device parallel to other affixation functions. The creations of Chinese characters, as well as German and Chinese sign languages, illustrate well the primitive stage of reduplication's iconic function, demonstrating conceptual structures that reflect our perception of the relationship between material entities.

10 See also the analysis in the Introduction. 


\section{References}

Ait-Hamou, Khaled. 1979. Structure et typologie de la quantification dans les langues naturelles (Document de linguistique quantitative $\mathrm{N}^{\circ} 36$ ). Paris : Jean-Favard.

Association of Chinese deaf persons. 2003. Zhongguo shouyu [Chinese Sign Language]. Beijing: Huaxia chubanshe.

Baxter, William H. 1992. A Handbook of Old Chinese phonology. (Trends in Linguistics Studies and Monographs 64). Berlin/New York: Mouton de Gruyter.

Behr, Wolfgang. 2006. "Homosomatic juxtaposition" and the problem of "syssemantic" (huì yì) characters. In Ecriture chinoise. Données, usages et représentations [Chinese writing. Data, use and representations], Françoise Bottéro and Redouane Djamouri (eds.), 75-114. Paris: EHESS/CRLAO.

Bisang, Walter. 2012. Numeral classifiers with plural marking. A challenge to Greenberg. This volume.

Bo, Wenze. 2003. Studies of the Mulao. Beijing: Minzu chubanshe.

Chang, Hong'en. 1986. Outline of the Lahu Grammar. Beijing: Minzu chubanshe.

Chen, Guoqing. 2002. Studies of the Kemu. Beijing: Minzu chubanshe.

Chen, Guoqing. 2005. Studies of the Kemie. Beijing: Minzu chubanshe.

Chen, Xiaoyun. 1988. Hasake yu zhong ci de chongdie [Reduplicated words in Kazakh]. Minzu Yuwen 3: 44-50.

Comrie, Bernard. 2008. The Areal Typology of Chinese: Between North and Southeast Asia. In Chinese Linguistics in Leipzig CLE 2, Redouane Djamouri, Barbara Meisterernst and Rint Sybesma (eds.), 1-21.

Croft, William. 1990. Typological and Universals. Cambridge: Cambridge University Press.

Dai, Qingxia. 2005. Studies of the Langsu. Beijing: Minzu chubanshe.

Dai, Qingxia and Jiang Ying. 2004. Mengya qi liangci de leixingxue tezheng-Jingpo yu liangci de ge'an yanjiu [Typological characteristics of classifiers at a primitive stage-the case of Jingpo], Studies on Sino-Tibetan languages: Papers in honor of Professor Hwang-Cherng Gong on his seventieth Birthday, 315-325. Taipei: Academia Sinica.

Downing, Pamela. 1996. Numeral Classifier System: The Case of Japanese. Amsterdam/ Philadelphia: John Benjamins Publishing Company.

Dryer, Matthew S. 1992. The Greenbergian word order correlations. Language, Volume 68: 1, 81-138.

Feng, Shengli. 2009. Hanyu de yunlü, cifa yu jufa [Interactings between Morphology, Syntax and Prosody in Chinese] (revised edition). Beijing: Beijing Univeristy Press.

Gao, Yongqi. 2003. Studies of the Mang. Beijing: Minzu chubanshe.

Gao, Yongqi. 2004. Studies of the Buxing. Beijing: Minzu chubanshe.

Givón, Talmy. 1983. Iconicity, isomorphism, and non-arbitrary coding in syntax. In Iconicity in Syntax, John Haiman (ed.), 187-219. Amsterdam/Philadelphia: John Benjamins Publishing Company.

Greenberg, Joseph. 1972. Numeral classifiers and substantival number: problems in the genesis of a linguistic type. Language Universals 9: 1-39.

Guo, Pan. 2004. Hanyu sheshu wenti yanjiu [Studies on numbers in Chinese]. Beijing: Zhonghua shuju.

Hagège, Claude. 1985. Le chinois, l'ordre des mots et l'ordre du pensable [Chinese, word order and the order of the thinkable]. T'oung Pao LXXI: 263-274. 
Hagège, Claude. 2005. Word classes in isolating languages. In Lexicology, D. Alan Cruse et al. (eds.), vol. 2: 976-980. Berlin: Walter de Gruyter.

Haiman, John. 1980. The Iconicity of grammar: Isomorphism and motivation. Language 56: 3, 515-540.

Haiman, John (ed.). 1985. Iconicity in Syntax. Amsterdam/Philadelphia: John Benjamins Publishing Company.

Haspelmath M., M. S. Dryer, D. Gil and B. Comrie (eds.). 2005. The World Atlas of Language Structures. Oxford: Oxford University Press.

The World Atlas of Language Structures Online (WALS Online).

He, Jiren and Jiang Zhuyi. 1985. Outline of Naxi Grammar. Beijing: Minzu chubanshe.

Hurch, Bernhard (ed.). 2005. Grammar, Comparative and general-Reduplication. Berlin/New York: Mouton de Gruyter.

Jin, Haiyue. 2005. Han-Chao yu shuliang duanyu de xingshi ji yuyi bijiao [Syntactic and semantic comparison of numeral classifiers in Chinese and Korean]. In Han-Zang yuxi liangci yanjiu [Studies of classifiers in Sino-Tibetan], Li Jinfang and Hu Suhua (eds.), 499505. Beijing: Zhongyang minzu daxue chubanshe.

Kiyomi, Setsuko. 1995. A new approach to reduplication: a semantic study of noun and verb reduplication in the Malayo-Polynesian languages. Linguistics 33: 1145-1167.

Lakoff, George and Mark Johnson. 1980. Metaphors We Live by. Chicago: The University of Chicago Press.

Li, Daqin. 2002. Studies of the Geman. Beijing: Minzu chubanshe.

Li, Daqin. 2004. Studies of the Sulong. Beijing: Minzu chubanshe.

Li, Jinfang. 1999. Studies of the Buyang. Beijing: Zhongyang minzu daxue chubanshe.

Li, Xulian. 1999. Studies of the Lai. Beijing: Zhongyang minzu daxue chubanshe.

$\mathrm{Li}$, Yongsui. 2002. Studies of the Kongsang. Beijing: Zhongyang minzu daxue chubanshe.

Li, Yongsui. 2002. Studies of the Sangkong. Beijing: Zhongyang minzu daxue chubanshe.

Li, Yunbing. 2000. Studies of the Laji. Beijing: Zhongyang minzu daxue chubanshe.

$\mathrm{Li}$, Yunbing. 2005. Studies of the Bugeng. Beijing: Minzu chubanshe.

Liang, Min and Zhang Junru. 2002. Studies of the Biaohua. Beijing: Minzu chubanshe.

Lin, Lianyun. 1985. Outline of the Salar Grammar. Beijing: Minzu chubanshe.

Liu, Guangkun. 1998. Studies of the Mawo Qiang. Chengdu: Sichuan minzu chubanshe.

Liu, Danqing. 2003. Yuxu Leixingxue yu Jieci Lilun [Word Order Typology and a Theory of

Adposition]. Beijing: Commercial Press.

Lu, Shaozun. 2001. Studies on Pumi Dialects. Beijing: Minzu chubanshe.

Lu, Shaozun. 2002. Studies on Menba Dialects. Beijing: Minzu chubanshe.

Mao, Zongwu. 2004. Studies on the Mian of Yao. Beijing: Minzu chubanshe.

Mao, Zongwu and Li, Yunbing. 2002. Studies of the Jiongnai. Beijing: Zhongyang minzu daxue chubanshe.

Mao, Zongwu, Meng Chaoji and Zheng Zhongze. 1982. Outline of the Yao language Grammar. Beijing: Minzu chubanshe.

Michaud, Alexis and Morgenstern Aliyah (eds.). 2007. Faits de Langues N29: La Réduplication. Paris: Ophrys.

Moravcsik, Edith A. 1978. Reduplicative constructions. In: Greenberb J. (ed.) Universals of Human Languages Vol. 3, 297-334. Stanford: Stanford University Press.

Mu, Shihua. 2003. Studies on the Kazhuo. Beijing: Minzu chubanshe.

Ortmann, Albert. 2000. Where plural refuses to agree: Feature unification and morphological economy. Acta Linguistica Hungarica, Vol. 47: 249-288. 
Ouyang, Jueya, Cheng Wan and Yu Cuirong. 1984. Outline of the Jing Grammar. Beijing: Minzu chubanshe.

Paris, Marie-Claude. 2007. Un aperçu de la réduplication nominale et verbale en mandarin [Survey of nominal and verbal reduplications in Mandarin]. Faits de Langues 29: La Réduplication, 63-76. Paris: Ophrys.

Peyraube, Alain. 2000. Ordre des constituants en chinois archaïque [Order of constituents in Old Chinese]. In Ordre des mots et typologie linguistique [Word Order and linguistic typology], Anaïd Donabédian and Xu Dan (eds.), 99-110. (Cahiers de Linguistique de l'INALCO 3.)

Pfau, Roland and Markus Steinbach. 2005. Backward and sideward reduplication in German Sign Language. In Grammar, Comparative and general-Reduplication, Bernhard Hurch (ed.), 569-594. Berlin/New York: Mouton de Gruyter.

Rubino, Carl. 2005. Reduplication: Form, function and distribution. In Grammar, Comparative and general-Reduplication, Bernhard Hurch (ed.), 11-29. Berlin/New York: Mouton de Gruyter.

Sagart, Laurent. 1999. The Roots of Old Chinese. Amsterdam/Philadelphia: John Benjamins Publishing Company.

Sanches, Mary. 1973. Reprint. Numeral classifiers and plural marking: an implicational universal. Language Universals 11: 1-22, 1971.

Sapir, Edward. 1921. Language: An Introduction to the Study of Speech. New York: Harcourt, Brace, and World.

Sun, Hongkai, Huang Chenglong, Zhou Maocao. 2002. Studies of the Rouruo. Beijing: Zhongyang minzu daxue chubanshe.

Sun, Hongkai, Hu Zengyi and Huang Xing. 2007. Zhongguo de yuyan [The Languages in China]. Beijing: Commercial Press.

Sun, Hongkai and Liu Guangkun. 2005. Studies of the Anong. Beijing: Minzu chubanshe.

Swiggers, Pierre. 1993. Coup d'œil historiographique. Faits de Langues : Motivation et iconicité 1: 21-28.

Wang, Fushi. 1985. Outline of the Miao Grammar. Beijing: Minzu chubanshe.

Wang, Li. 1958. Outline of the Chinese Language History. Beijing: Kexue chubanshe.

Wang, Qingfeng. 2005. Studies of the Manchu. Beijing: Minzu chubanshe.

Xiang, Bolin. 2008. Studies of the Jiarong. Beijing: Minzu chubanshe.

$\mathrm{Xu}$, Dan. 2006. Typological Change in Chinese Syntax. Oxford: Oxford University Press.

$\mathrm{Xu}$, Dan. 2009a. Xiayou Shixingyu de mouxie tedian [Some syntactic features of Down-river Shixing]. Minzu yuwen 1: 25-42.

Xu, Dan. 2009b. Cong Zhanguo zonghengjia shu kan Xi Han chuqi fushu gainian de biaoda [Plurality in Chinese at early Han seen in the Zhanguo zonghengjia shu], Lishi yuyanxue yanjiu 2: 83-94. Beijing: Commercial Press.

$\mathrm{Xu}$, Dan and Fu, Jingqi. 2011. Liangci jiqi leixingxue kaocha [Classifiers and some typological considerations], Yuyan kexue [Sciences in linguistics], 6: 1-14.

$\mathrm{Xu}$, Lin and Zhao, Yansun. 1984. Outline of the Bai Grammar. Beijing: Minzu chubanshe.

Xuan, Dewu, Jin Xiangyuan, Zhao Xi. 1985. Outline of the Korean Grammar. Beijing: Minzu chubanshe.

Yang, Tongyin. 2000. Studies of the Mo. Beijing: Zhongyang minzu daxue chubanshe.

Zeitoun, Elizabeth. 2007. La réduplication en rukai mantauran. Faits de Langues 29: La Réduplication, 37-47. Paris: Ophrys.

Zhang, Jichuan. 1986. Outline of the Cangluo Menba Grammar. Beijing: Minzu chubanshe. 
Zhang, Junru. 1999. Studies on Zhuang Dialects. Chengdu: Sichuan minzu chubanshe.

Zhang, Min. 1997. Cong leixingxue he renzhi yufa de jiaodu kan hanyu chongdie xianxiang [Reduplication in Chinese - A typological and cognitive grammar study], Guowai Yuyanxue 2: 37-45.

Zhang, Min. (preprint a). From construction Grammar to construction morphology: an MSDT approach to Chinese symmetric constructions.

Zhang, Min. (preprint b). Ziran jufa lilun yu hanyu yufa xiansixing yanjiu [About naturalist grammar and iconicity in Chinese grammar].

Zhou, Maocao. 2003. Studies on Maqu Tibetan. Beijing: Minzu chubanshe.

Zhou, Yaowen and Luo, Meizhen. 2001. Studies on Dai Dialects. Beijing: Minzu chubanshe. 